\title{
Potensi Kandungan Metabolit Primer pada 10 Jenis Buah-Buahan Hutan
}

\author{
Heriad Daud Salusu* \\ Pengolahan Hasil Hutan, Politeknik \\ Pertanian Negeri \\ Samarinda, Samarinda, 75131 \\ risaldaud@gmail.com \\ *Corresponding author
}

\author{
Eva Nurmarini \\ Prodi Rekayasa Kayu, Politeknik \\ Pertanian Negeri Samarinda, \\ Samarinda, 75131, \\ evapriansyah10@yahoo.co.id
}

\author{
Hamka \\ Teknologi Hasil Perkebunan, \\ Politeknik Pertanian Negeri \\ Samarinda, Samarinda, 75131 \\ hamkanurkaya@gmail.com
}

\author{
Husmul Beze \\ Teknologi Rekayasa Perangkat \\ Lunak, Politeknik Pertanian Negeri \\ Samarinda, Samarinda, 75131 \\ husmul@politanisamarinda.ac.id
}

\author{
Yulianto \\ Teknologi Rekayasa Perangkat \\ Lunak, Politeknik Pertanian Negeri \\ Samarinda, Samarinda, 75131. \\ yulianto.tile@yahoo.com
}

\begin{abstract}
Abstrak - Tujuan dari penelitian ini adalah untuk mengetahui manfaat buah hutan yang dapat dimakan yang tediri dari 10 jenis buah yaitu rambai (Baccaurea motleyana), limpasu (Baccaurea lanceolatai), kapul (Baccaurea macrocarpa), manau rotan (Calamus manan Miq), sega rotan (Calamus caesius B1.), selekop (Lepisanthes amoenea), matoa (Pometia pinnata), ramania (Bouea macrophylla Griffith), kalangkala (Litsea angulata), dan lanciqn (Ficus obscura), sebagai sumber nutrisi melalui analisis metabolit primer yang terdiri dari karbohidrat, lemak, protein, kadar udara, kadar abu,

Sampel buah untuk pengujian metabolit primer adalah buah segar dimana bahagian buah yang diuji adalah daging buahnya. Analisis kadar air menggunakan metode oven, kadar protein menggunakan metode Kjeldahl, kadar lemak dengan metode ekstraksi soxhlet dan kadar karbohidrat menggunakan metode by difference.

Hasil penelitian menunjukkan buah pada kelompok jenis rotan atau family arecaceae (rotan manau dan rotan sega) memiliki kandungan protein lebih tinggi dari buah lainnya, sedangkan jenis buah dari family baccaurea (rambai, limpasu dan kapul) rendah pada kandungan protein dan lemak. Buah kalangkala mengandung lemak paling tinggi, diikuti buah selekop dan buah dari kelompok rotan.
\end{abstract}

Kata Kunci-karbohidrat, lemak, protein, buah, hutan.

\section{PENDAHULUAN}

Hutan sebagai sumber pangan khususnya penghasil buah-buahan belum begitu diperhitungkan sampai sekarang ini. Hal ini dapat dimaklumi karena dalam bidang kehutanan buah-buahan masih dianggap sebagai hasil hutan ikutan dan kurang memiliki nilai ekonomi yang baik dibanding dengan kayu. Pada kenyataannya potensi buah-buahan dalam hutan sangat melimpah hal ini dapat dilihat dari data bahwa tidak kurang dari 329 jenis buah-buahan (terdiri dari 61 suku dan 148 marga) baik yang merupakan jenis asli Indonesia maupun pendatang (introduksi) dapat ditemukan di Indonesia (Uji, 2007).

Beberapa jenis buah-buahan lokal dari hutan di Kalimantan Timur telah diperdagangkan secara tradisional oleh penduduk di sekitar hutan misalnya buah rambai, cempedak, mata kucing, kapul, jenis buah-buah rotan tertentu dan beberapa jenis lainnya, namun hanya dikenal secara terbatas dan masih asing bagi sebagian besar masyarakat. Umumnya orang lebih mengenal buahbuahan impor yang cukup mudah ditemukan baik di pasar-pasar tradisional dan pedagang buah maupun dalam pasar-pasar modern. Jenis-jenis buah seperti apel, anggur, pir, kiwi, anggur dan lain-lain merupakan buah yang sangat populer di masyarakat dibandingkan dengan buahbuahan hutan seperti kapul, ramania, rambai dan jenisjenis lainnya..

Pengetahuan tentang buah-buahan yang tumbuh di hutan atau buah-buahan lokal belum banyak diketahui mengingat minimnya penelitian yang dilakukan, padahal potensi buah sangat besar, selain itu buah setiap musim dapat dipanen sedangkan pohon sebagai sumber kayu sekali panen langsung habis ditebang dan harus menunggu lagi tumbuhan baru yang akan dipanen pada saat dewasa beberapa puluh tahun kemudian.

Berdasarkan uraian tersebut di atas, dalam peneltian disertasi ini telah dilakukan penelitian terhadap 10 (sepuluh) jenis buah-buahan hutan dimana kesepuluh jenis tersebut adalah buah yang dapat dimakan (edible fuit) yaitu buah rambai (Baccaurea motleyana), limpasu (Baccaurea lanceolata), kapul (Baccaurea macrocarpa), rotan manau (Calamus manan Miq.), rotan sega (Calamus caesius B1.), selekop (Lepisanthes amoenea), matoa (Pometia pinnata), ramania (Bouea macrophylla Griffith), kalangkala (Litsea angulata), dan lanciqn (Ficus obscura). Jenis buah-buahan tersebut merupakan buah endemik yang terdapat di wilayah Kalimantan 
kecuali buah matoa yang merupakan buah endemik kawasan timur Indonesia khususnya di Papua.

Tujuan dari penelitian ini adalah untuk mengetahui kandungan metabolit primer pada buah-buahan hutan yang diteliti meliputi kandungan air, kadar abu, protein, lemak dan karbohidrat. Hasil dari penelitian ini adalah rekomendasi untuk pengembangan buah-buahan hutan sehingga akan didapatkan manfaat dalam rangka peningkatan nilai hasil hutan bukan kayu.

\section{Metode Penelitian}

\section{A. Alat dan Bahan}

Peralatan yang dipakai dalam penelitian ini diantaranya adalah Labu Kjeldahl 300 mL, Buret, Satu set alat sokhlet, Oven, gelas ukur, labu ukur, gelas kimia, timbangan analitik, pipet tetes, erlenmeyer, corong, pengaduk, botol semprot, kertas saring, gegep, dan desikator. Sedangkan bahan-bahan yang digunakan dalam penelitian ini adalah 10 jenis buah-buahan, $\mathrm{H}_{2} \mathrm{SO}_{4}$ pekat, $\mathrm{HNO} 3$ pekat, aquades, $\mathrm{NaOH}-\mathrm{Na}_{2} \mathrm{~S}_{2} \mathrm{O}_{3}$ dan beberapa butiran zink, $\mathrm{HCl} 0,1 \mathrm{~N}, \mathrm{NaOH} 0,1 \mathrm{~N}$ dan petroleum benzine.

\section{B. Prosedur Pengujian}

1. Kandungan air Metode Oven (Sudarmadji dkk, 2010) Sejumlah 5 gram sampel dimasukkan ke dalam cawan yang telah diketahui bobotnya. Kemudian cawan dimasukkan ke dalam oven bersuhu $105^{\circ} \mathrm{C}$ hingga diperoleh bobot konstan. Perhitungan kandungan air dilakukan dengan mengunakan rumus :

$$
\begin{aligned}
& \text { Kandungan air }(\%)=\frac{W 1-(W 2-W o)}{W 1} \times 100 \% \\
& \text { Di mana : } \\
& \text { W2 = bobot cawan dan sampel akhir }(\mathrm{g}) \\
& W 1=\text { bobot sampel awal }(\mathrm{g}) \\
& \text { Wo = bobot cawan }(\mathrm{g})
\end{aligned}
$$

2. Kadar Abu (Andarwulan, 2011)

Cawan porselin dikeringkan dalam tanur bersuhu $600^{\circ} \mathrm{C}$ selama 1 jam kemudian didinginkan dalam desikator dan ditimbang. Sebanyak 5 gram sampel ditimbang dan dimasukkan ke dalam cawan porselin. Selanjutnya sampel dipijarkan di atas nyala pembakar bunsen sampai tidak berasap lagi, kemudian dilakukan pengabuan di dalam tanur listrik pada suhu $600^{\circ} \mathrm{C}$ selama 6 jam sampai terbentuk abu berwarna putih. Sampel kemudian didinginkan dalam desikator, selanjutnya ditimbang. Kadar abu dihitung dengan rumus :

$$
\text { Kadar abu }(0)=\frac{\text { berat abu }(\mathrm{g})}{\text { berat sampel }(\mathrm{g})} \times 100 \%
$$

3. Kadar Protein (AOAC, 1999)

Analisis kadar protein dapat diuji menggunakan metode Kjeldahl, yaitu dengan memasukkan sebanyak 0,1 gram sampel, 2,5 $\mathrm{ml} \mathrm{H}_{2} \mathrm{SO}_{4}$ pekat dan 1 gram katalis ke dalam labu Kjeldahl, kemudian didestruksikan hingga menghasilkan larutan jernih kehijauan dan didinginkan. Dinding labu Kjeldahl dicuci dengan aquades dan didihkan selama 30 menit. Setelah dingin lalu ditambahkan $40 \mathrm{ml}$ aquades, ditambahkan $10 \mathrm{ml}$ larutan $\mathrm{NaOH}-\mathrm{Na}_{2} \mathrm{~S}_{2} \mathrm{O}_{3}$ dan beberapa butiran zink. Larutan didistilasi dan distilat ditampung erlenmeyer $100 \mathrm{ml}$ yang berisi $10 \mathrm{ml}$ larutan $\mathrm{HCl} 0,1 \mathrm{~N}$ dan ditambahkan beberapa tetes indikator phenolptalein (PP). Larutan yang didapatkan ditittrasi dengan $\mathrm{NaOH} 0,1 \mathrm{~N}$, dan dilakukan pula tittrasi terhadap blanko. Total $\mathrm{N}$ atau $\%$ protein dalam sampel dihitung dengan perhitungan jumlah total $\mathrm{N}$ sebagai berikut :

$$
\mathrm{N} \text { total }(\%)=\frac{(\mathrm{mlNaOH} \text { blanko }-\mathrm{ml}(\mathrm{NaOH} \text { sampal) } \times \mathrm{NNaOH} \times 14,008 \times 100}{\text { berat sampel }(\mathrm{g}) \times 100}
$$

4. Kadar Lemak (Andarwulan, 2011)

Analisis kadar lemak dapat ditentukan dengan menimbang 2 gram bahan yang telah dihaluskan (yang sudah bebas air atau menggunakan bahan bekas penentuan kandungan air). Sampel yang telah ditimbang selanjutnya dimasukkan ke dalam kertas saring, dilipat kemudian dimasukkan ke dalam tabung ekstraksi Soxhlet, lalu air pendingin dilairkan melalui kondensor. Tabung ekstraksi dipasang pada alat distilasi Soxhlet dengan pelarut petroleum benzine secukupnya selama 4 jam. Setelah residu dalam tabung reaksi diaduk, ekstraksi dilanjutkan lagi selama 2 jam dengan pelarut sama. Petroleum benzine yang telah mengandung ekstrak lemak dan minyak dipindahkan ke dalam botol timbang yang bersih dan diketahui beratnya kemudian diuapkan dengan penangas air sampai agak pekat. Pengeringan diteruskan dalam oven bersuhu $100^{\circ} \mathrm{C}$ sampai diperoleh berat konstan. Jika beratnya telah konstan maka jumlah minyak pada sampel dapat diketahui dengan menggunakan rumus

$$
\begin{aligned}
& \text { Kadarminyak }(\%)(\mathrm{b} / \mathrm{b})=\frac{\text { berat lemak }(\mathrm{g}) \times 100}{\text { berat sampel }(\mathrm{g})}=\frac{(\mathrm{B}-\mathrm{A}) \times 100}{\text { berat sampel }} \times 100 \% \\
& \text { Di mana : } \\
& \text { A }=\text { Berat labu kosong dan batu didih }(\mathrm{g}) \\
& \text { B }=\text { Berat labu dan ekstrak minyak }(\mathrm{g})
\end{aligned}
$$

5. Kadar Karbohidrat (Andarwulan, 2011)

Kadar karbohidrat dengan metode by difference merupakan penentuan kadar karbohidrat secara kasar dimana bukan berdasarkan analisis melainkan melalui perhitungan. Kadar karbohidrat diperoleh dengan menggunakan rumus :

\section{Kadar Karbohidrat $=100 \%-\%($ protein + lemak + abu + air $)$}

\section{Metode Penelitian}

Pengujian metabolit primer terhadap 10 jenis buah-buahan hutan meliputi kandungan protein, karbohidrat, dan lemak, selain itu dilakukan juga pengujian terhadap kandungan air dan kadar abu. Hasil pengujian terdapat pada Tabel 6 . 
Tabel 1. Kandungan Metabolit Primer pada 10 Jenis Buah-buahan Hutan

\begin{tabular}{|c|c|c|c|c|c|c|}
\hline \multirow{2}{*}{ No } & Jenis Buah & \multicolumn{5}{|c|}{ Kandungan Proksimat (\%) } \\
\cline { 3 - 7 } & $\mathrm{K} \mathrm{A}$ & $\begin{array}{c}\mathrm{K} . \\
\mathrm{Abu}\end{array}$ & Protein & Lemak & $\begin{array}{c}\text { Karbo- } \\
\text { hidrat }\end{array}$ \\
\hline 1. & $\begin{array}{c}\text { Rambai } \\
\text { (Baccaurea motleyana) }\end{array}$ & 82,11 & 0,45 & 0,39 & 0,01 & 17,04 \\
\hline 2. & $\begin{array}{c}\text { Limpasu } \\
\text { (Baccaurea lanceolate) }\end{array}$ & 80,36 & 9,55 & 0,52 & 0,03 & 9,54 \\
\hline 3. & $\begin{array}{c}\text { Kapul } \\
\text { (Baccaurea } \\
\text { macrocarpa) }\end{array}$ & 85,05 & 0,33 & 1,44 & 0,17 & 13,01 \\
\hline 4. & $\begin{array}{c}\text { Rotan Manau } \\
\text { (Calamus manan Miq.) }\end{array}$ & 18,30 & 2,19 & 7,35 & 1,24 & 70,92 \\
\hline 5. & $\begin{array}{c}\text { Rotan Sega (Calamus } \\
\text { caesius Blume) }\end{array}$ & 19,68 & 1,40 & 5,82 & 1,48 & 71,62 \\
\hline 6. & $\begin{array}{c}\text { Selekop } \\
\text { (Lepisanthes amoenea) }\end{array}$ & 19,48 & 2,69 & 1,75 & 3,49 & 72,59 \\
\hline 7. & $\begin{array}{c}\text { Matoa (Pometia } \\
\text { pinnata) }\end{array}$ & 73,28 & 1,39 & 1,27 & 0,91 & 23,15 \\
\hline 8. & $\begin{array}{c}\text { Ramania (Bouea } \\
\text { macrophylla Griffith) }\end{array}$ & 77,60 & 1,10 & 2,45 & 0,74 & 18,11 \\
\hline 9. & $\begin{array}{c}\text { Kalangkala } \\
\text { (Litsea angulata) }\end{array}$ & 78,13 & 2,38 & 1,49 & 6,53 & 11,47 \\
\hline 10. & Lanciqn (Ficus obscura) $)$ & 85,40 & 3,89 & 1,53 & 0,26 & 8,92 \\
\hline
\end{tabular}

Tabel 1 menunjukkan data kandungan metabolit primer dari sepuluh jenis buah-buahan hutan yang bervariasi pada tiap-tiap jenis, hal ini dikarenakan karakter tumbuh dan variasi tempat tumbuh serta perbedaan jenis. Kadangkala pada jenis yang sama terdapat perbedaan kandungan gizi karena dipengaruhi oleh serapan unsur hara dari tumbuhan itu sendiri di mana jumlah kebutuhan ini berkaitan dengan kebutuhan tumbuhan agar dapat tumbuh dengan baik. Selain itu tempat tumbuh dan kandungan unsur hara dalam tanah yang berbeda-beda pada setiap tempat turut berkontribusi terhadap hal ini.

Data pada Tabel 1 menunjukkan kandungan air pada tujuh jenis buah (rambai, limpasu, kapul, matoa, ramania, kalangkala dan lanciqn) rata-rata diatas $70 \%$ sedangkan unsur lainnya terutama karbohidrat di bawah $25 \%$, sedangkan pada rotan manau, rotan sega dan selekop kandungan airnya rata-rata di bawah $20 \%$ sebaliknya kandungan karbohidratnya rata-rata di atas $70 \%$. Hal ini menunjukkan kandungan air dan karbohidrat saling berkaitan komposisinya dalam buah yang diuji.

Secara umum buah pada kelompok jenis rotan atau family arecaceae (rotan manau dan rotan sega) memiliki kandungan protein lebih tinggi dari buah lainnya, sedangkan jenis buah dari family baccaurea (rambai, limpasu dan kapul) rendah pada kandungan protein dan lemak. Buah kalangkala mengandung lemak paling tinggi, diikuti buah selekop dan buah dari kelompok rotan.

Berikut ini diuraikan masing-masing komponen yang terkandung dalam buah-buahan yang diuji.

\section{A. Kandungan air}

Air merupakan komponen penting dalam bahan makanan, karena dapat mempengaruhi penampakan, tekstur serta cita rasa makanan. Selain itu kandungan air dalam bahan makanan juga menentukan acceptability (penerimaan), kesegaran dan daya tahan bahan itu. Kandungan air secara umum diperlukan untuk kelangsungan proses biokimia organisme hidup. Kandungan air dalam bahan pangan berperan sebagai pelarut dan pereaksi dari beberapa komponen. Bentuk kandungan air dapat ditemukan sebagai air bebas dan air terikat. Air bebas dapat dengan mudah hilang apabila terjadi penguapan atau pengeringan, sedangkan air terikat sulit dibebaskan dengan cara tersebut. Air dapat terikat secara fisik, yaitu ikatan menurut sistem kapiler dan air terikat secara kimia, antara lain air kristal dan air yang terikat dalam sistem dispersi (Purnomo, 1995).

Buah-buahan umumnya mengandung kandungan air yang tinggi yaitu dalam kisaran $65-90 \%$ kadar protein dan lemak rendah (Muchtadi, 2008). Menurut de Ita dkk. (2015), secara umum komposisi air yang terkadung dalam buah dan sayuran adalah air 80-90\%, karbohidrat $20-25 \%$, serat $2 \%$, vitamin, protein, lemak, mineral, aroma dan pigmen kurang dari 0,5\%. Kehilangan air pada buah dan sayuran terjadi pada suhu rendah, kemudian meningkat pada suhu $100-150^{\circ} \mathrm{C}$, kemudian pada suhu $150-200^{\circ} \mathrm{C}$ kehilangan air pada struktur dan semua komponen lainnya, dan mendekati suhu $300^{\circ} \mathrm{C}$ terjadi kerusakan struktur dan perubahan komponen dalam bentuk gas berupa $\mathrm{CO}, \mathrm{CO}_{2}$ dan lainnya.

Beberapa jenis buah yang memiliki kandungan air cukup tinggi diantaranya adalah arbei $89,9 \%$, jeruk keprok 87,3\%, jambu air 87\%, papaya $86,7 \%$, dan alpukat $84,3 \%$ (Muchtadi, 2008). Selanjutnya dijelaskan bahwa buah-buahan yang kaya akan air merupakan salah satu sumber gula alami, asam amino, garam mineral dan vitamin, hal ini sangat bermanfaat untuk mengurangi ketergantungan pada makanan dan minuman buatan yang mengandung hal serupa.

Hasil penelitian menunjukkan terdapat tujuh jenis buah yang memiliki kandungan air diatas $70 \%$ berturutturut matoa $(73,28 \%)$, ramania $(77,6 \%)$, kalangkala $78,13 \%$, limpasu $(80,36 \%)$, rambai $(82,11 \%)$, Kapul $(85,05 \%)$, dan lanciqn $(85,40 \%)$. Sedangkan tiga jenis buah lainnya yaitu rotan sega, rotan manau dan selekop memiliki kandungan air yang rendah dibawah yaitu $20 \%$. Beberapa jenis buah yang mengandung kandungan air rendah diantaranya adalah buah kom (Ziziphus Mauritania Lam) 33,70\%, buah mentega bisbul (Diospyros blancoi) 8,90\%, buah keranji (Diallium indum L.) $20,10 \%$, buah atung (Parinarium glaberrimum Hassk) 9,20\% dan buah kedondong masak 58\% (Mahmud dkk., 2009), menunjukkan bahwa tidak selamanya kandungan air pada buah tinggi tetapi pada jenis-jenis tertentu kandungan airnya rendah.

\section{B. Kadar Abu}

Abu adalah residu anorganik dari proses pembakaran atau oksidasi komponen organik bahan pangan. Kadar abu total adalah bagian dari analisis proksimat yang bertujuan untuk mengevalusi nilai gizi suatu produk/bahan pangan terutama total mineral.

Kadar abu buah-buahan segar menurut Sudarmadji dkk. (2010) berkisar antara 0,2-0,8\% namun data hasil penelitian memperlihatkan bahwa rata-rata kadar abu berkisar $2 \%$ kecuali buah limpasu dengan kadar abu $9,55 \%$. Beberapa data hasil penelitian pada beberapa jenis buah menunjukkan hal yang hampir serupa seperti pada buah nipa (Nypa fructicans) kadar abunya sekitar 1,01\% (Herman dkk., 2011), buah pir ( Pyrus communis) pada 
kulit sebesar 2,22\%, daging buah $5,34 \%$ dan biji $1,6 \%$ (Mahammad dkk., 2010).

\section{Karbohidrat}

Karbohidrat adalah sumber energi utama tubuh. merupakan zat gizi yang terdapat dalam makanan yang tersusun dari unsur karbon $(\mathrm{C})$, hydrogen $(\mathrm{H})$, dan oksigen $(\mathrm{O})$ yang mempunyai rumus $\left(\mathrm{CH}_{2} \mathrm{O}\right)_{n}$. Di dalam tubuh karbohidrat akan dibentuk dengan beberapa asam amino dan sebagain dari gliserol lemak, namun sebagian besar pula karbohidrat diproleh dengan bahan makanan yang dikonsumsi sehari-hari, terutama yang berasal dari tumbuh-tumbuhan/tanaman.

Karbohidrat merupakan hasil utama fotosintesis oleh tumbuhan hijau yang kelebihannya disimpan di tempat-tempat penyimpanan ca dangan makanan termasuk buah, merupakan makro nutrien penting karena sebagai sumber energi utama bagi sebagian besar makhluk. Selain sebagai sumber energi, karbohidrat juga berfungsi sebagai cadangan makanan, pemberi rasa manis pada makanan, penghemat protein karena bila karbohidrat makanan terpenuhi, protein terutama akan digunakan sebagai zat pembangun. Karbohidrat juga berfungsi sebagai pengatur metabolisme lemak karena karbohidrat mampu mencegah oksidasi lemak yang tidak sempurna.

Pada perkembangan buah, perubahan karbohidrat terjadi selama pemasakan buah. Pada buah muda, karbohidrat masih banyak dalam bentuk pati sehingga rasa buah tidak manis. Selama proses pematangan buah, melalui reaksi enzimatis, pati akan dipecah menjadi gula sederhana seperti glukosa, fruktosa dan sukrosa sehingga buah menjadi manis. Buah akan menjadi lebih manis setelah asam organik atau molekul pati diubah menjadi gula yang biasa mencapai konsentrasi $20 \%$ pada buah matang. Fitriningrum dkk.,(2013) dalam penelitiannya terhadap buah karika (Carica pubescens) menyatakan bahwa terdapat perubahan kandungan karbohidrat pada berbagai tingkat kematangan buah yaitu ada kecenderungan semakin matang buah semakin meningkat kandungan karbohidrat totalnya, namun pada kandungan serat kasarnya semakin menurun.

Berdasarkan data hasil penelitian seperti yang terdapat pada Tabel 6 di atas menunjukkan terdapat tiga jenis buah yang memiliki kandungan karbohidrat cukup tinggi diatas $70 \%$ yaitu selekop $72,59 \%$, rotan manau 70 , $92 \%$ dan rotan sega $71,62 \%$ dan tujuh jenis buah lainnya karbohidrat rata-rata $14,46 \%$ atau dalam rentang $8,92 \%$ sampai $23,15 \%$. Jika dibandingkan dengan beberapa jenis buah yang telah diteliti kandungan karbohidratnya diantaranya buah dari jenis Chrysophyllum albidum mengandung karbohidrat pada daging buah sebesar $66,45 \%$, pada biji $65,22 \%$ dan pada kulit $64,7 \%$ (Ibrahim dkk., 2017), begitupun dengan buah mangrove (Sonneratia caseolaris) mempunyai kandungan karbohidrat yang tinggi yaitu sebesar 77,57\% (Manalu dkk., 2013).

Umumnya buah dengan kandungan air tinggi mengandung karbohidrat yang rendah. Muchtadi (2008) memaparkan beberapa jenis buah dengan kisaran kandungan karbohidrat antara 7\%-30\% diantaranya adalah pepaya $12,2 \%$, apel $14,9 \%$, mangga golek $16,7 \%$, dan pisang raja $31,2 \%$ pada tujuh jenis buah yang diteliti dalam penelitian ini. Buah alpukat memiliki kandungan karbohidrat sekitar 8-9 \% (Marsigit dkk., 2016). Mundaragi dkk. (2017), dalam studinya terhadap lima belas jenis buah-buahan minor di India melaporkan kandungan karbohidrat rata-rata $17,57 \%$.

\section{Protein}

Protein adalah nutrisi yang sudah umum diketahui, manfaatnya sangatlah vital yaitu untuk meningkatkan fungsi otak, untuk pembentukan otot tubuh dan banyak manfaat lainnya. Kekurangan asupan protein menimbulkan masalah kesehatan yang serius, dimana bagian-bagian tubuh tidak mampu berfungsi dengan normal. Oleh karena itu, nutrisi protein harus dipenuhi dalam setiap harinya.

Protein adalah senyawa organik kompleks berbobot molekul tinggi yang merupakan polimer dari monomer-monomer asam amino yang dihubungkan satu sama lain dengan ikatan peptida. Tumbuhan menyerap unsur-unsur hara dalam tanah melalui akar dan disalurkan keseluruh bagian tanaman sampai ke daun sehingga tumbuhan membentuk protein dan melakukan perombakan (proses katabolisme) (Andarwulan dkk., 2011).

Protein yang terdapat pada buah atau tumbuhan pada umumnya biasa disebut protein nabati. Protein pada bagian tumbuhan terdapat hampir dalam seluruh bagian tubuh tumbuhan. Protein ditemukan pada daun muda dan pada bagian tubuh lainnya seperti polong, dan buah. Beberapa penelitian menunjukkan keberadaan protein yang memiliki letak berbeda-beda pada tumbuhan. Pada famili serealia seperti gandum, padi, polong-polongan dan jagung protein berada pada bagian bijinya. Pada tanaman tembakau, protein banyak ditemukan dibagian daunnya. Sedangkan pada kantong semar, protein banyak ditemukan pada bagian antara batang dengan bunga (Manalu dkk., 2013).

Kandungan protein pada kesepuluh jenis buah yang diuji menunjukkan bahwa dua jenis buah rotan memiliki kandungan protein dibandingkan buah lainnya yaitu buah rotan manau sebesar $7,35 \%$ dan buah rotan sega $5,82 \%$, sedangkan buah yang lainnya rata-rata kandungan proteinnya $1,5 \%$. Jika dibandingkan dengan buah-buahan lainnya seperti buah mangrove (Sonneratia caseolaris) 9,21\% (Manalu dkk, 2013), terong liar (Solanum incanum) mengandung protein $7,80 \%$, buah pir (Pyrus communis) 26\% (Mahammad dkk., 2010) menunjukkan bahwa kedua jenis buah rotan dapat dijadikan sebagai salah satu sumber protein nabati.

\section{E. Lemak}

Lemak merupakan salah satu senyawa organik golongan ester yang terdapat yang banyak terdapat pada tumbuhan, hewan atau manusia. Lemak pada suhu kamar berbentuk cair disebut minyak sedangkan istilah lemak biasanya digunakan untuk yang berwujud padat (Saragih, 2016).

Lemak atau lipida terdiri dari unsur karbon, hidrogen dan oksigen. Fungsi utama cadangan lemak dan minyak dalam biji-bijian adalah sebagai sumber energi. 
Cadangan ini merupakan salah-satu bentuk penyimpanan energi yang penting bagi pertumbuhan.

Sebagian besar buah dan sayuran mengandung kadar lemak rendah. Apel, jeruk, melon, sayuran hijau, wortel, kentang dan seledri mengandung kadar lemak rendah. Buah dan sayuran tertentu mengandung kadar lemak yang relatif tinggi. Alpukat, buah zaitun, biji, kelapa dan produk kedelai seperti tahu memiliki kadar lemak tinggi. Mayoritas lemak yang ditemukan dalam makanan ini adalah lemak tak jenuh tunggal atau tak jenuh ganda, yang merupakan bentuk lemak sehat.

Data hasil penelitian menunjukkan kandungan lemak dalam 10 jenis buah yang diteliti antara 0,01-6\% dimana buah kalangkala memiliki kandungan lemak paling tinggi sebesar $6,53 \%$ sedangkan buah rambai mengandung lemak $0,01 \%$. Buah kalangkala memiliki karakter daging buah mirip buah alpukat baik dari segi rasa maupun tekstur, buah ini jika dikonsumsi biasanya direndam dalam air panas terlebih dahulu. Buah alpukat sendiri memiliki kandungan lemak cukup tinggi yaitu sebesar 20,6\% pada daging buahnya (Yahia, 2012), dan pada bijinya mengandung lemak $11,40 \%$ (Wibowo, 2016). Beberapa jenis buah lainnya yang mengandung lemak cukup tinggi diantaranya buah mangrove $4,82 \%$, dan Chrysophyllum albidum 6,97\% (Ibrahim dkk., 2017). Tidak semua jenis buah mengandung lemak tinggi, Mundaragi dkk. (2017), dalam penelitiannya terhadap 15 jenis buah-buahan yang kurang dikenal di India menunjukkan rata-rata mengandung lemak sekitar $0,72 \%$. Data pada Tabel 6 di atas menunjukkan terdapat delapan jenis buah yang mengandung lemak yang rendah antara 0,01\%-1,48\% yaitu rambai, limpasu, lanciqn, kapul, matoa, ramania, rotan manau dan rotan sega.

\section{KESIMPULAN}

Secara keseluruhan buah rotan (rotan manau dan rotan sega) memiliki kandungan protein yang lebih tinggi dari jenis buah lainnya disusul oleh buah ramania, kadar lemak tertinggi pada buah kalangkala dan buah selekop, dan untuk karbohidrat tertinggi pada buah selekop rotan sega dan rotan manau.

\section{DAFTAR PUSTAKA}

Andarwulan, N.; F. Kusnandar dan Herawati. 2011. Analisis Pangan. Dian Rakyat, Jakarta

Anonim. 1999. AOAC: Official Method of Analysis (Volume I). Association of Official Analitycal Chemists Inc, Arlington Virginia, USA.

de Ita, A.; G. Flores and F. Franco. 2015. Fruits and vegetables dehydration. Journal of Physics: Conference Series 582(2015) 012065 doi:10.1088/1742-6596/582/1/012065

Fitriningrum, R.; Sugiyarto; dan A. Susilowati. 2013. Analisis Kandungan Karbohidrat pada Berbagai Tingkat Kematangan Buah Karika (Carica pubescens) di Kejajar dan Sembungan, Dataran Tinggi Dieng, Jawa Tengah. Bioteknologi 10(1): 6-14, doi: 10.13057/biotek/c100102.
Ibrahim, H; O. Osilesi; O. Adebawoi; K. Funmilayo; Kayode Lb and Muhammad. (2017). Nutrients Compositions and Phytochemical Contents of Edible Parts of Chrysophyllum albidum Fruit. . 10.4172/2155-9600.1000579.

Mahammad, M.U.; A.S. Kamba; L. Abubakar and E.A. Bagna. 2010. Nutritional Composition of Pear Fruits (Pyrus communis). African Journal of Food Science and Technology, 1(3):076-81.

Mahmud, M.K.; Hermana, N.A.; Zulfianto, R.R.; Apriyantono, I.; Ngadiarti, B.; Hartati; Bernadus; dan Tinexcelly. 2009. Tabel Komposisi Pangan Indonesia. PT. Elex Media Komputindo. Jakarta.

Manalu, R.D.A.; E. Salamah; F. Retiaty dan N. Kurniawati. 2013. Kandungan Zat Gizi Makro dan Vitamin Produk Buah Pedada (Sonneratia caseolaris). Penelitian Gizi dan Makanan, 36(2): 135-140

Marsigit, W; M. Astuti; S. Anggrahini dan S. Naruki. 2016. Kandungan Gizi, Rendemen Tepung, dan Kadar Fenol Total Alpukat (Persea americana Mill) Varietas Ijo Panjang dan Ijo Bundar. AGRITECH, 36(1): 48-55

Muchtadi, T.R. 2008. Jenis dan Varietas Hortikultura. PANG4226/MODUL 1, Universitas Terbuka, Jakarta.

Mundaragi, A; T. Devarajan; S. Bhat and Jeyabalan. 2017. Proximate Analysis and Mineral Composition of Potential Minor Fruits of Western Ghats of India. Scientific Papers. Series A. Agronomy, Vol. LX.

Purnomo, H. 1995. Aktifitas Air dan Peranannya dalam Pengawetan Pangan. UI Press. Jakarta.

Saragih, B. 2016. Pangan, Gizi dan Kesehatan. Mulawaman University Press, Samarinda.

Sudarmadji, S.: B. Haryono dan Suhardi. 2010. Prosedur Analisa Untuk Bahan Makanan dan Pertanian. Liberty, Yogyakarta.

Uji, T. 2007. Review: Keanekaragaman Jenis BuahBuahan Asli Indonesia dan Potensinya. Biodiversitas, 8(2): 157-167.

Wibowo, A. 2016. Identifikasi Kandungan Zat Makanan pada Biji Buah-Buahan di Pasar Bandar Lampung. Skripsi, Jurusan Peternakan Fakultas Pertanian Universitas Lampung, Bandar Lampung.

Yahia, E. 2012. Avocado. Crop Post-Harvest. Science and Technology: Perishables. 159-186. Doi.10.1002/9781444354652.ch8. 